\title{
PENGGUNAAN MODEL PEMBELEJARAN BLENDED LEARNING TERHADAP HASIL BELAJAR MATEMATIKA KELAS VIII DI SMPN 38 SURABAYA
}

\author{
Akhbar Galang $\mathbf{M}^{\mathbf{1}}$, Wahyuni Suryaningtiyas ${ }^{2}$, Febriana Kristanti ${ }^{3}$ \\ Program Studi Pendidikan Matematika, FKIP UMSurabaya \\ akhbargalangmarhendra@yahoo.com ${ }^{1}$, yunisurya@gmail.com ${ }^{2}$, \\ febrianatanti@gmail.com ${ }^{3}$
}

\begin{abstract}
ABSTRAK
Permasalahan dalam penelitian ini adalah masih banyaknya pendidik dan peserta didik yang belum memaksimalkan akses internet di era globalisasi saat ini, kurangnya pendidik dalam menguasai model pembelajaran e-learning digunakan dalam mengajar, serta masih banyak pula pendidik dan peserta didik SMPN 38 Surabaya yang belum menggunakan secara maksimal fasilitas wifi guna mencari sumber belajar yang berguna untuk mengemas materi agar lebih luas dan bervairiasi.

Penelitian ini termasuk penelitian eksperimen. Desain yang digunakan dalam penelitian ini adalah Pretest-Posttest Control Group Design. Penelitian dilakukan di SMPN 38 Surabaya. Sampel dalam penelitian adalah kelas VIII B sebagai kelas eksperimen dan kelas VIII E sebagai kelas kontrol.

Hasil penelitian menunjukkan bahwa, pengaruh model pembelajaran Blended Learning terhadap hasil belajar matematika yang dilakukan pada kelas VIII SMPN 8 Surabaya, dapat disimpulkan bahwa model pembelajaran Blended Learning berpengaruh positif dan signifikan terhadap hasil belajar siswa. Hal ini dilihat dari adanya perbedaan positif hasil belajar siswa antara kelas kontrol dan kelas eksperimen. Hasil belajar siswa pada kelas eksperimen lebih baik daripada hasil belajar pada kelas kontrol. Selain itu, Pada hasil angket respon siswa, terlihat bahwa $42 \%$ siswa (pada pernyataan angket positif) sangat setuju dan $32 \%$ setuju dengan penggunaan model pembelajaran Blended Learning dalam pembelajaran matematika, ini berarti bahwa banyak siswa pada kelompok kelas eksperimen merespon baik terhadap penggunaan model pembelajaran Blended Learning dalam pembelajaran matematika di kelas.
\end{abstract}

Kata Kunci : Blended Learning, Model Pembelajaran, Pembelajaran Matematika

\section{PENDAHULUAN}

Perkembangan teknologi komunikasi tersebut juga berdampak pada dunia pendidikan. Pada kenyataan saat ini, jika pendidikan dihubungkan dengan teknologi, maka akan jelas terlihat bahwa pendidikan sangat memerlukan bantuan teknologi. Hal tersebut terlihat pada penggunaan teknologi canggih di dalam kelas yang digunakan guru saat mengajar. Pemanfaatan teknologi dalam dunia pendidikan khususnya dalam sistem pembelajaran telah mengubah sistem pembelajaran konvensional menjadi sistem pembelajaran modern yang berasaskan teknologi informasi dan komunikasi (Information and Communication Technology [ICT]). Salah satu diantaranya adalah media komputer dengan internetnya yang pada akhirnya memunculkan e-learning. Diharapkan dari penggunaan media 
teknologi informasi dan komunikasi agar siswa dapat tertarik mengikuti pembelajaran di dalam kelas.

Beberapa model pembelajaran diterapkan guru dengan maksud agar siswa mudah memahami materi pembelajaran yang disampaikan. Menurut Keller (2014:143), model pembelajaran sebagai "tiruan atau contoh kerangka konseptual yang melukiskan prosedur pembelajaran secara sistematis dalam mengelola pengalaman belajar peserta didik agar tujuan belajar terentu yang diinginkan dapat tercapai”.

Salah satu model pembelajaran tersebut adalah Blended Learning. Menurut Moebs dan Weibelzahl (dalam Husamah, 2014:12) Blended Learning adalah pencampuran antara online dan pertemuan tatap muka (face-to-face meeting) dalam suatu aktivitas pembelajaran yang terintegrasi. Model pembelajaran ini menggabungkan model pembelajaran secara konvensional dengan teknologi. Jika dahulu pembelajaran hanya terpusat pada guru namun sekarang terfokus pada siswa. Jika penyampaian materi pembelajaran hanya berfokus pada tatap muka, dimungkinkan siswa akan jenuh dalam menerima pembelajaran atau kekurangan waktu untuk materi tambahan, sedangkan jika memanfaatkan teknologi dan komunikasi saat ini peseta didik dapat melakukan pembelajaran kapan saja dan dimana saja. Menurut Garnham (dalam Husamah, 2014:21), tujuan dikembangkan Blended Learning adalah untuk menggabungkan ciri terbaik pembelajaran di kelas (tatap muka) dan online untuk meningkatkan pembelajaran mandiri secara aktif oleh peserta didik dan mengurangi waktu tatap muka di kelas. Adapun komponen yang mendukung berjalannya pembelajaran Blended Learning sebagai berikut: 1) face to face learning, 2) e-learning offline, 3) e-learning online, 4) mobile learning.

Sudah terdapat banyak fasilitas yang mendukung berlangsungnya model pembelajaran Blended learninng di SMPN 38. Misalnya melalui jaringan wifi yang digunakan untuk mengakses website yang mendukung sumber belajar, komunikasi antara guru dengan siswa, dan memberikan tugas kepada siswa yang sifatnya tidak perlu tatap muka didalam kelas.

Berdasarkan uraian di atas, dapat mendeskripsikan perbedaan hasil belajar matematika yang signifikan antara siswa yang belajar menggunakan model pembelajaran Blended Learning dengan yang tanpa model pembelajaran Blended 
Learning, Mendeskripsikan aktifitas dan respon siswa dalam pembelajaran matematika menggunakan model pembelajaran Blended Learning pada siswa kelas VIII di SMPN 38 Surabaya.

\section{METODE PENELITIAN}

Jenis penelitian yang digunakan merupakan penelitian eksperimen. Karena penelitian ini bertujuan untuk mengetahui ada tidaknya pengaruh model pembelajaran Blended Learning yang signifikan terhadap Hasil belajar siswa. Penelitian ini dilakukan pada dua kelas dalam satu sekolah dengan cara membandingkan dua kelas tersebut yaitu kelas kontrol dan kelas eksperimen. Pada kelas eksperimen diterapkan pembelajaran dengan menggunakan model pembelajaran Blended Learning sedangkan pada kelas kontrol menggunakan pendekatan konvensional.

Desain yang digunakan dalam penelitian ini adalah True Experimental Design. Dengan desain ini, peneliti dapat mengontrol semua variabel luar yang mempengaruhi jalannya eksperimen (Sugiyono, 2010:112). Salah satu bentuk dari True Eksperimental Design yaitu Pretest-Posttest Control Group Design. Desain yang dilakukan dengan membandingkan kelompok yang diberikan perlakuan (X) melalui skor yang diperoleh dari pelaksanaan pretest dan posttest. Tujuan melakukan eksperimen ini adalah mengetahui perbedaan yang signifikan antara hasil tes awal (pretest) dan tes akhir (posttest) pada kelas eksperimen dan kelas kontrol serta dari tes awal dan tes akhir tersebut terlihat ada pengaruh atau tidaknya perlakuan (treatment) yang telah diberikan.

Adapun desain penelitian yang digunakan dalam penelitian ini adalah

\begin{tabular}{|cccc|}
\multicolumn{4}{c|}{ Desain Penelitian } \\
$\mathrm{R}$ & Pretest & Perlakuan & Postest \\
$\mathrm{R}$ & $O_{1}$ & $\mathrm{X}$ & $O_{2}$ \\
& $O_{1}$ & & $O_{2}$ \\
\hline
\end{tabular}

Gambar 1.1 Desain Penelitian 


\section{Keterangan:}

$\mathrm{R}=$ Kelas eksperimen dan kelas kontrol siswa SMPN 38 Surabaya yang diambil secara random.

$\boldsymbol{O}_{\mathbf{1}}=$ Kedua kelas tersebut diobservasi dengan melakukan pemberian pretest untuk mengetahui nilai kemampuan awal siswa/ hasil belajar awalnya.

$\boldsymbol{O}_{2}=$ Kedua kelas tersebut diobservasi dengan melakukan pemberian posttest untuk mengetahui nilai kemampuan akhir siswa/ hasil belajar akhirnya.

$\mathbf{X}=$ Treatment/ perlakuan. Kelompok atas sebagai kelas eksperimen yang diberikan treatment, yakni pembelajarannya dengan menggunakan model pembelajaran Blended Learning.

Penelitian eksperimen ini dilaksanakan di SMPN 38 Surabaya pada kelas VIII yang dipilih secara random. Penelitian ini dilaksanakan pada dua kelas dengan jumlah siswa masing-masing kelas 28 siswa. Penelitian ini dimulai 28 Mei 2015 sampai dengan 12 Juni 2015.

Sampel yang diambil dalam penelitian ini yaitu dengan mengambil 2 kelas, VIII E dan B dari keseluruhan kelas VIII yang ada pada SMPN 38 Surabaya tersebut. Satu kelas dijadikan sebagai kelas eksperimen dan satu kelas lagi sebagai kelas kontrol.

Dalam penelitian ini peneliti menggunakan teknik pengumpulan data tes tulis (pre test dan post test), angket, observasi dan dokumentasi.

Instrumen penelitian yang digunakan dalam penelitian ini terdiri dari: (1) Seperangkat tes ini terdiri dari 10 soal esai yang akan dikerjakan oleh siswa secara invidu. Soal tes ini digunakan dalam soal pretest 5 soal dan posttest 5 soal. (2) Seperangkat Angket ini digunakan untuk mengetahui seberapa respon siswa terhadap model pembelajaran Blended Learning dalam pembelajaran matematika.

Langkah-langkah yang dilakukan untuk mengolah data hasil pretest dan posttest: (1) Menguji normalitas data hasil pretest dan posttest pada kelas ekserimen dan kelas kontrol dengan tujuan untuk mengetahui apakah data skor pretest sampel berasal dari populasi yang berdistribusi normal. Untuk menguji kenormalan distribusi pada kelas eksperimen dan kelas kontrol dapat digunakan uji kolmogorov-smirnov. Pengujian kolmogorov-smirnov menggunakan kecocokan kumulatif sampel $\mathrm{X}$ dengan distribusi probabilitas normal. Rumus yang digunakan yaitu: 


$$
k=\left|f\left(Z_{i}\right)-S\left(Z_{i}\right)\right|
$$

\section{Keterangan:}

$f\left(Z_{i}\right)=$ Probabilitas kumulatif normal

$S\left(Z_{i}\right)=$ Probabilitas kumulatif empiris

(2) Melakukan uji homogenitas data hasil pretest dan posttest dengan tujuan untuk mengetahui kesamaan dua varians antara kelas eksperimen dan kelas kontrol. Untuk menguji kesamaan varians yang bedistribusi normal digunakan uji homogenitas. Pasangan hipotesis yang akan diuji adalah :

$H_{0}$ : Tidak ada perbedaan varians dalam hasil belajar matematika pada kelas eksperimen dan kelas kontrol.

$H_{1}$ : Ada perbedaan varians dalam hasil belajar matematika pada kelas eksperimen dan kelas kontrol.

Kriteria pengujian :

Terima $H_{0}$ untuk $F_{\text {hitung }} \leq F_{\text {tabel }}$

$$
F_{\text {hitung }}=\frac{S_{1}^{2}}{S_{2}^{2}}
$$

\section{Keterangan:}

$S_{1}^{2}=$ Varians terbesar

$S_{2}^{2}=$ Varians terkecil

Rumus Varians adalah :

$$
S_{i}^{2}=\frac{n \Sigma f_{i} x_{i}^{2}-\left(\Sigma f_{i} x_{i}\right)^{2}}{n(n-1)}
$$

(3)Melakukan uji perbedaan dua rata-rata (Uji $t$. Uji $t$ diperlukan untuk mengetahui ada tidaknya perbedaan rata-rata kemampuan siswa dalam matematika antara kelas eksperimen dan kelas kontrol. Karena data kedua sampel yang akan diteliti mempunyai jumlah yang kecil ( $\mathrm{N}$ kurang dari 30) dan antara dua sampel (kelas eksperimen dan kelas kontrol) tidak ada hubungannya maka rumus uji $t$ yang digunakan adalah :

$$
t_{0}=\frac{M_{1}-M_{2}}{S E_{M_{1}-M_{2}}}
$$

(Sudijono, 2010:314) 


\section{Keterangan:}

$M_{1}=$ Mean skor tes akhir pada kelas eksperimen

$M_{2}=$ Mean skor tes akhir pada kelas kontrol

$S E=$ Standard error mean

(4) Penarikan Kesimpulan. Jika $H_{0}$ ditolak maka $H_{1}$ diterima. Jika $H_{1}$ diterima maka akan ada perbedaan yang signifikan antara kelas yang diberi perlakuan dengan kelas yang tidak diberi perlakuan. Apabila terbukti ada perbedaan antara kelas eksperimen dan kelas kontrol maka dilakukan uji satu pihak. Statistik uji satu pihak dapat dirumuskan sebagai berikut :

$$
t=\frac{\bar{x}-\mu}{s / \sqrt{n}}
$$

\section{Keterangan:}

$$
\begin{aligned}
& t=\text { nilai } \mathrm{t} \text { yang dihitung } \\
& \bar{x}=\text { Rata-rata } x_{1} \\
& \mu \quad=\text { nilai yang dihipotesiskan }
\end{aligned}
$$

Analisis data nontes berupa data observasi sikap, keterampilan, aktifitas siswa dan angket pada penelitian ini menggunakan teknik analisis data deskriptif. Selanjutnya data tersebut diolah menggunakan rumus :

$$
\text { Nilai }=\frac{\text { skor yang diperoleh }}{\text { skor masksimal }} \times 100 \%
$$

Untuk pernyataan dalam angket yang hanya terdiri dari pernyataan positif. Dalam menganalisis data yang berasal dari angket tersebut dilakukan dengan cara memberikan skor pada setiap jawaban penilaian tersebut dapat dilihat pada Tabel 3.3 di bawah ini:

\section{Tabel 1.1 Penilaian Pernyataan}

\begin{tabular}{|l|c|c|}
\hline No & Jawaban & Nilai \\
\hline 1 & Sangat Setuju (SS) & 4 \\
\hline 2 & Setuju (S) & 3 \\
\hline 3 & Tidak Setuju (TS) & 2 \\
\hline 4 & Sangat Tidak Setuju (STS) & 1 \\
\hline
\end{tabular}




\section{HASIL PENELITIAN DAN PEMBAHASAN}

Pretest dan posttest dilaksanakan guna memperoleh data hasil belajar matematika pada aspek kognitif dengan menggunakan soal berbentuk uraian sebanyak 5 butir soal dengan harapan nilai maksimal yang didapat ialah 100 . Pemberian pretest dilakukan pada kelas eksperimen dan kelas kontrol sebelum dilaksanakan pembelajaran, kemudian dilakukan pembelajaran matematika dengan menggunakan model pembelajaran Blended Learning pada kelas eksperimen, serta pada kelas kontrol hanya dilakukan pembelajaran matematika dengan menggunakan metode pembelajaran konvensional. Setelah semua materi disampaikan dan telah dipelajari oleh siswa maka dilakukan tes akhir (posttest) pada kelas eksperimen dan kelas kontrol dengan tujuan untuk mengetahui hasil belajar matematika akhir siswa pada aspek kognitifnya.

Sebelum instrumen digunakan dalam penelitian, instrumen dikonsultasikan kepada dosen pembimbing dan guru matematika di sekolah serta di uji coba kepada siswa di luar sampel yang diikuti sebanyak 20 siswa guna mengetahui kualitas atau kelayakan instrumen yang digunakan. Adapun hasil uji coba instrumen tes didapatkan validitas dan reabilitas sebagai berikut:

Berdasarkan hasil perhitungan, diperoleh nilai validitas dan reabilitas bernilai signifikan untuk $\alpha \leq 0,01$ dengan $n=20$, dan bernilai signifikan untuk $\alpha \leq 0,05$ dengan $n=20$.

Berdasarkan Tabel rekapitulasi nilai pretest, perolehan nilai di atas KKM yaitu nilai lebih besar atau sama dengan 75, kelas eksperimen dan kelas kontrol mendapatkan persentase $0 \%$, sedangkan perolehan nilai di bawah KKM yaitu nilai kurang dari atau sama dengan 75 , kelas eksperimen dan kelas kontrol mendapatkan persentase $100 \%$.

Berdasarkan Tabel rekapitulasi nilai posttest di atas, perolehan nilai di atas KKM yaitu nilai lebih besar atau sama dengan 75 , kelas eksperimen mendapatkan persentase $96,43 \%$ dan kelas kontrol mendapatkan persentase 3,57\%, sedangkan perolehan nilai di bawah KKM yaitu nilai kurang dari atau sama dengan 75, kelas eksperimen mendapatkan persentase $0 \%$ dan kelas kontrol mendapatkan persentase $100 \%$. 
Pada uji normalitas data pretest, nilai $K S_{\text {hitung }}$ dengan taraf signifikan kedua kelas tersebut 0,05 adalah 0,146 untuk kelas eksperimen dan 0,148 untuk kelas kontrol. Nilai kritis $K S_{\text {Tabel }}$ dengan taraf nyata 0,05 adalah 0,257. Karena $K S_{\text {Tabel }}=$ $0,257>K S_{\text {hitung }}=0,146$ untuk kelas ekperimen dan $K S_{\text {Tabel }}=0,257>K S_{\text {hitung }}=$ 0,148 untuk kelas kontrol maka data prestest kelas eksperimen dan kelas kontrol yang diperoleh dinyatakan berdistribusi normal.

Pada uji homogenitas data pretest diperoleh angka signifikansinya (Sig.) yaitu 0,094. Karena nilai signifikansinya lebih dari $\alpha=0,05$ atau $P$-value $>\alpha$ maka $\mathrm{H}_{0}$ diterima, yang artinya data hasil Pretest kelas eksperimen dan kelas kontrol bersifat homogen atau memiliki varian yang sama. Dapat disimpulkan bahwa tidak terdapat perbedaan hasil belajar matematika siswa awal pada kelas kontrol dan kelas eksperimen. Kemudian pada uji $t$-Test terlihat bahwa nilai thitung pada uji $t$ Test for Equality of Means dengan taraf signifikan kedua kelas tersebut 0,05 adalah 0,072. Dengan nilai kritis $t_{\alpha / 2}$ dan $-t_{\alpha / 2}$ taraf nyata 0,05 dan $d f=54$ adalah 2.0049 dan -2.0049. Karena $-t_{\alpha / 2}=-2.0049<t_{\text {hitung }}=0,072<t_{\alpha / 2}=2.0049$, maka $H_{0}$ diterima. Maka dapat disimpulkan bahwa tidak terdapat perbedaan rata-rata skor pretest antara kelas kontrol dan kelas eksperimen.

Setelah diketahui bahwa kedua kelas sampel mempunyai kemampuan awal yang sama, maka langkah selanjutnya yaitu dilakukan pembelajaran matematika menggunakan model pembelajaran Blended Learning pada kelas eksperimen dan pembelajaran konvensional pada kelas kontrol. Setelah dilaksanakan pembelajaran dan semua materi telah disampaikan, baru dilakukan tes akhir (posttest), yang bertujuan untuk mengetahui hasil belajar siswa dalam belajar matematika pada kelas kontrol dan kelas eksperimen.

Pada pengolahan data posttest diperoleh bahwa nilai $K S_{\text {hitung }}$ dengan taraf signifikan kedua kelas tersebut 0,05 adalah 0,156 untuk kelas eksperimen dan 0,144 untuk kelas kontrol. Nilai kritis $K S_{\text {Tabel }}$ dengan taraf nyata 0,05 adalah 0,257. Karena $K S_{\text {Tabel }}=0,257>K S_{\text {hitung }}=0,156$ untuk kelas ekperimen dan $K S_{\text {Tabel }}=0,257$ $>K S_{\text {hitung }}=0,144$ untuk kelas kontrol maka data posttest kelas eksperimen dan kelas kontrol yang diperoleh dinyatakan berdistribusi normal. Maka dapat diambil kesimpulan bahwa sampel kelas kontrol dan kelas eksperimen dinyatakan berdistribusi normal. 
Pada uji $t$-Test terlihat bahwa nilai thitung pada uji t-Test for Equality of Means dengan taraf signifikan kedua kelas tersebut 0,05 adalah 13,508. Dengan nilai kritis $t_{\alpha / 2}$ dan $-t_{\alpha / 2}$ taraf nyata 0,05 dan $d f=54$ adalah 2.0049 dan -2.0049 . Karena $t_{\text {hitung }}=$ 13,508 > $t_{\alpha / 2}=2.0049$, maka $H_{0}$ ditolak dan alternatif $H_{1}$ diterima. Dari hasil pengujian di atas, dapat disimpulkan bahwa terdapat perbedaan rata-rata skor posttest antara kelas eksperimen dan kelas kontrol.

Pada uji One-Sample Test terlihat bahwa nilai thitung $=2,504$ pada uji OneSample Test dan nilai $t_{\text {Tabel }}$ untuk taraf nyata 0,05 dan $d f=27$ adalah 2.052. Karena $t_{\text {tabel }}=2.052<t_{\text {hitung }}=2,504$, maka $H_{0}$ ditolak dan alternatif $\mathrm{H}_{1}$ diterima, Sehingga didapatkan hasil bahwa Hasil belajar dengan menggunakan model pembelajaran Blended Learning lebih baik daripada yang tidak menggunakan model Blended Learning. Confidence interval lower sebesar 0,8021 dan upper sebesar 8,1234 dari confidence interval menunjukkan hasil positif tidak melewati angka 0. Dari perolehan tersebut dapat dikatakan bahwa model pembelajaran Blended Learning lebih baik.

Berdasarkan analisis data penilaian sikap diperoleh data bahwa kelas eksperimen lebih baik dibandingkan dengan kelas kontrol juga pada analisis data penilaian keterampilan menunjukkan kelas eksperimen lebih baik daripada kelas kontrol. Pada analisis data aktifitas siswa dalam pembelajaran matematika menggunakan model pembelajaran Blended Learning di atas dapat disimpulkan bahwa aktifitas siswa yang paling dominan terjadi dalam pembelajaran matematika menggunakan model pembelajaran Blended Learning adalah aktifitas siswa "Aktif dalam mengemukakan pendapat" dimana presentasenya mencapai $22.77 \%$ dan aktifitas siswa yang paling minim terjadi pada pembelajaran menggunakan model pembelajaran Blended Learning adalah aktifitas siswa "Mempresentasikan hasil penyelesaian dari tugas yang guru berikan" dengan presentase hanya $4.46 \%$.

Berdasarkan hasil angket respon siswa terlihat bahwa $42 \%$ siswa (pada pernyataan angket positif) setuju dengan penggunaan model pembelajaran Blended Learning dalam pembelajaran matematika, ini berarti bahwa banyak siswa pada kelompok kelas eksperimen merespon baik terhadap penggunaan model pembelajaran Blended Learning dalam pembelajaran matematika di kelas. 


\section{SIMPULAN}

Berdasarkan analisis hasil penelitian yang telah dilkaukan oleh peneliti mengenai pengaruh model pembelajaran Blended Learning terhadap hasil belajar matematika yang dilakukan pada kelas VIII SMPN 38 Surabaya, dapat disimpulkan bahwa:

1. Model pembelajaran Blended Learning berpengaruh positif dan signifikan terhadap hasil belajar siswa. Hal ini dilihat dari nilai $t_{\text {hitung }}=2,504$ pada uji OneSample Test dan nilai $t_{\text {tabel }}$ untuk taraf nyata 0,05 dan $d f=27$ adalah 2,052. Karena $t_{\text {tabel }}=2,052<t_{\text {hitung }}=2,504$, maka $H_{0}$ ditolak dan alternatif $\mathrm{H}_{1}$ diterima. Jadi dapat disimpulkan, Hasil belajar siswa pada kelas eksperimen lebih baik daripada hasil belajar pada kelas kontrol.

2. Berdasarkan analisis data penilaian sikap diperoleh data bahwa kelas eksperimen lebih baik dibandingkan dengan kelas kontrol juga pada analisis data penilaian keterampilan menunjukkan kelas eksperimen lebih baik daripada kelas kontrol. Pada analisis data aktifitas siswa dalam pembelajaran matematika menggunakan model pembelajaran Blended Learning di atas dapat disimpulkan bahwa aktifitas siswa yang paling dominan terjadi dalam pembelajaran matematika menggunakan model pembelajaran Blended Learning adalah aktifitas siswa "Aktif dalam mengemukakan pendapat" dimana presentasenya mencapai $22.77 \%$ dan aktifitas siswa yang paling minim terjadi pada pembelajaran menggunakan model pembelajaran Blended Learning adalah aktifitas siswa "Mempresentasikan hasil penyelesaian dari tugas yang guru berikan" dengan presentase hanya $4.46 \%$.

3. Pada hasil angket respon siswa, terlihat bahwa $42 \%$ siswa (pada pernyataan angket positif) sangat setuju dan 32\% setuju dengan penggunaan model pembelajaran Blended Learning dalam pembelajaran matematika, ini berarti bahwa banyak siswa pada kelompok kelas eksperimen merespon baik terhadap penggunaan model pembelajaran Blended Learning dalam pembelajaran matematika di kelas. 


\section{DAFTAR PUSTAKA}

Husamah. 2014. Pembelajaran Bauran (Blended Learning). Jakarta: Prestasi Pustaka.

Keller, Helen. 2014. Strategi Pembelajaran Teori dan Aplikasi. Jogjakarta: ArRuzz Media.

Sudjana, Nana. 2009. Penilaian Hasil Proses Belajar Mengajar. Bandung: PT Remaja Rosda Karya.

Sugiyono. 2010. Metode Penelitian Pendidikan Pendekatan Kuantitatif, Kualitatif, dan $R \& D$. Bandung: Alfabeta. 